\title{
KEPASTIAN HUKUM AKAD MURABAHAH PADA JUAL BELI RUMAH MELALUI PERBANKAN SYARIAH
}

\author{
Zulfikri* \\ *Fakultas Hukum Universitas Islam Riau (UIR) Pekanbaru \\ Jl. Kaharuddin Nasuition No. 113 Perhentian Marpoyan Pekanbaru 28284 \\ Email : zulfikripohan@law.uir.ac.id
}

\begin{abstract}
ABSTRAK: Akad murabahah adalah jual-beli barang pada harga asal dengan tambahan keuntungan yang sudah disepakati, Pelaksanaan akad ini menggunakan dua bentuk perjanjian yaitu konvensional dan syariah, bagaimana kepastian hukum akad ini ditinjau dari segi hukum positif Indonesia adalah penting untuk dipahami. Metode yang digunakan dalam penelitian ini adalah dengan pendekatan penelitian hukum normatif (law research) namun di perkuat dengan data empiris. Sumber data berasal dari data primer dan sekunder, data tersebut kemudian dianalisa dengan menggunakan analisa secara logis. Penarikan kesimpulan dengan cara deskriptif metode deduktif. Hasil penelitian ini adalah Penerapan Akad Murabahah untuk membeli rumah dengan Pembiayaan Pemilikan Rumah (PPR) pada BRI Syariah Pekanbaru tidak dapat dijalankan secara murni sesuai dengan Keputusan DSN. No. 04/ DSN-MUI/ 2000 tentang Murabahah. Kepastian hukum pelaksanaan Akad Murabahah yang menggunakan wakalah merupakan kreasi hukum; Akad murabahah merupakan kepastian hukum alamiah/ natural certainty contract. Dengan demikian, sifat transaksinya fixed (tetap), dan predetermined (dapat ditentukan besarnya) dari sisi ini akad Murabahah lebih baik dari Perjanjian Kredit Bank Konvensional.
\end{abstract}

Kata Kunci : Murabahah, Jual beli, Perbankan Syariah 


\section{PENDAHULUAN}

Prakarsa untuk mendirikan Bank Islam di Indonesia sudah dilakukan sejak tahun 1990 (Antonio, 2001). Majelis Ulama Indonesia (MUI) pada tanggal 18-20 Agustus 1990 menyelenggarakan Lokakarya Bunga Bank dan Perbankan di Cisarua, Bogor, Jawa Barat. Hasil lokakarya itu dibahas lebih mendalam pada Musyawarah Nasional IV MUI yang berlangsung di Hotel Sahid Jaya Jakarta, 2225 Agustus 1990. Berdasarkan amanat Munas IV MUI, dibentuklah kelompok kerja untuk mendirikan bank Islam di Indonesia (Antonio, 2001) Keberadaan perbankan syariah di Indonesia semakin dirasakan, walaupun awalnya belum ada aturan hukum yang rinci tentang perbankan syariah tersebut. Khususnya dalam pola operasional yang mengatur aktivitas usahanya (Syukri, 2000)

Sejak tahun 2011 tepatnya setelah dua tahun lembaga keuangan ini mempunyai payung hukum sendiri yakni Undang-Undang Nomor 21 Tahun 2008 tentang Perbankan Syariah yang sebelumnya diatur melalui Undang-Undang Nomor 10 Tahun 1998 tentang perubahan Undang-Undang Nomor 7 Tahun 1992 tentang perbankan. Pada dasarnya bank syariah dan konvensional adalah samasama lembaga keuangan yang menjalankan aktivitas bisnis dan mengedepankan keuntungan. Namun dalam tataran filosofis dan aplikasi, sesungguhnya kedua bentuk sistem keuangan ini memiliki perbedaan yang sangat signifikan. Baik dalam hal semangat dasar, landasan operasional hingga pada produk yang ditawarkan (Adiwarman, 2001). Adapun perbedaan keduanya terletak pada filosofi of economics, bukan pada science of economics. Sebab pandangan Islam mengenai ekonomi mempunyai karakteristik yang tidak terdapat pada sistem ekonomi modern. Islam memiliki acuan dasar Al-Quran dan Hadist serta acuan yang bersifat interpretative (M.Faruk, 2001).

Murabahah produk bank syariah menjauhkan ketidak pastian yang ada pada pendapatan dari bisnis-bisnis dengan sistem profit and loss sharing (PLS). Murabahah tidak memungkinkan bankbank Islam untuk mencampuri manajemen bisnis, karena bank bukanlah mitra nasabah karena hubungan mereka dalam murabahah adalah hubungan antara kreditur dan debitur. Akad murabahah merupakan natural certainty contract, yaitu suatu jenis kontrak transaksi dalam bisnis yang memiliki kepastian keuntungan dan pendapatan baik dari segi jumlah maupun dari segi penyerahannya. Adapun yang dimaksud dengan memiliki kepastian adalah masingmasing pihak yang terlibat dapat melakukan prediksi terhadap pembayaran maupun waktu pembayarannya. Dengan demikian, sifat transaksinya fixed (tetap), dan predetermined (Sunarto, 2003).

Dasar penggunaan perjanjian murabahah tersebut adalah melandaskan pada fatwa Dewan Syariah Nasional (DSN) Nomor 04/DSN-MUI/IV/2000 tentang Murabahah (Adrian, 2009). Sedangkan dasar hukum pemberlakuan jual beli murabahah ini, dapat dilihat dalam Al Qur'an surat Al-Baqarah ayat 275 yang artinya:

"Orang-orang yang makan (mengambil) riba tidak dapat berdiri melainkan seperti berdirinya orang yang kemasukan syaitan lantaran (tekanan) penyakit gila. Keadaan mereka yang demikian itu, adalah disebabkan mereka berkata (berpendapat), 
sesungguhnya jual beli itu sama dengan riba, padahal Allah telah menghalalkan jual beli dan mengharamkan riba. Orang-orang yang telah sampai kepadanya larangan dari Tuhannya, lalu terus berhenti (dari mengambil riba), maka baginya apa yang telah diambilnya dahulu (sebelum datang larangan); dan urusannya (terserah) kepada Allah. Orang yang kembali (mengambil riba), Maka orang itu adalah penghuni-penghuni neraka; mereka kekal di dalamnya (Alquran, Albaqarah, 275) .

Salah satu produk murabahah yang telah dikembangkan oleh bank yakni pembiayaan rumah, atau yang sering dikenal dengan istilah Pmbiayaan Pemilikan Rumah (PPR) Murabahah, adalah pinjaman jangka panjang yang diberikan bank bekerja sama dengan pengembang (developer) untuk memberikan kemudahan bagi konsumen agar memiliki rumah sendiri dengan pembayaran sistem angsuran kepada bank. Fasilitas PPR Murabahah ini sangat prospektif bagi bank. Sehingga hampir semua bank selalu menyediakan fasilitas ini untuk memenuhi kebutuhan masyarakat akan rumah (Johanes, 2004). Pemberian pembiayaan oleh bank syariah kepada nasabah debitur yang dilakukan berdasarkan perjanjian pembiayaan, seringkali terdapat kelemahan dalam prosesnya. Dapat menimbulkan risiko kerugian bagi bank sebagai pihak yang meminjamkan dana, maupun si peminjam sehingga kepastian hukum sangatlah penting. Tanpa adanya kepastian hukum pelaku-pelaku ekonomi khawatir akan keselamatan diri mereka antara lain karena tindakan perdata dapat dijadikan pidana karena aturan hukum tidak konsisten (Erman, 2012).

$$
\text { Wakalah dalam transaksi }
$$

murabahah terjadi melalui proses perwakilan antara pihak perbankan kepada nasabah. Dimana pihak perbankan mewakilkan kepada pihak nasabah untuk melakukan pembelian sendiri barang yang diinginkan kepada supplier setelah mendapatkan uang pembelian dari bank. Praktik murabahah semacam ini menyerupai transaksi kredit pada perbankan konvensional. Karena dalam murabahah yang diselipkan akad wakalah penyerahan bukan dalam bentuk barang tetapi dalam bentuk uang cash hal ini juga dipraktikkan dalam perbankan konvensional melalui pinjaman kredit .

Murabahah model ini sudah tidak murni lagi karena pihak bank syariah tidak murni sebagai penjual barang seperti pada industri perdagangan yang menjual barang secara langsung kepada pembeli, karena pada umumnya bank tidak mempunyai persediaan barang, bank juga bukan sebagai agen investasi karena tidak menawarkan barang yang menjadi obyek jual-beli (Bagya, 2009). Tentunya konsep seperti ini dimungkinkan mengandung unsur jual beli inah. Karena bank telah membeli barang dari nasabah dengan kontan, lalu dalam waktu yang bersamaan bank menjualnya kembali barang tersebut ke nasabah dengan tempo/jangka waktu dan dengan harga yang lebih tinggi dari harga pembelian. Praktik ini dikategorikan inah di mana para ulama sepakat akan keharamannya (AlAtsyaniyah, 2015). Dikhawatirkan masih ada unsur riba dalam jual beli tersebut, karena bank meminjamkan uang senilai barang yang dibeli kepada nasabah di saat itu lalu bank mengharapkan 
pengembaliannya dengan tempo dan jumlah nominal yang lebih tinggi dari nominal pinjaman.

Bank Rakyat Indonesia (BRI Syariah) Pekanbaru merupakan pemecahan dari BRI Konvensional, salah satu bank syariah yang menerapkan akad Murabahah dalam memberikan fasilitas bagi masyarakat yang akan membeli rumah dari developer. Dalam pelaksanaannya apabila masyarakat ingin memiliki rumah tetapi uangnya tidak cukup maka dapat mengajukan pembiayaannya melalui BRI Syariah.

Dengan gambaran kedua akad tersebut dapat dipahami, sesungguhnya secara nyata tidak ada jual beli antara bank dengan developer sebagai pemilik rumah, makna rumah yang dikuasakan kepada nasabah untuk mencari rumah yang diinginkannya bukanlah milik bank. Apanila bank menganggap rumah tersebut adalah milik bank tentu bank memiliki akte jual beli yang menyatakan bank sebagai pemiliknya, atau akte kuasa jual, atau akte hibah dan sebagainya, ternyata tidak ada dokumen yang dapat dilihat bahwa bank adalah pemilik rumah yang hendak dimiliki nasabah. Dengan demikian jual beli rumah antara bank dengan nasabah bertentangan dengan keputusan DSN No. 4/ 2000 tentang Murabahah yang mengharuskan bank harus memiliki barang terlebih dahulu barulah boleh menjual kepada nasabah.

\section{TINJAUAN PUSTAKA}

\section{Tinjauan umum Bank Syariah}

Bank Syariah adalah istilah khusus di Indonesia, sedangkan dinegara lain sering disebut dengan Bank Islam. Ada perbedaan yang paling pokok dari bank umum dengan bank syariah dimana terletak pada sitem maupun jenis produk perbankan. Khususnya bank Syariah tidak mengenal apa yang disebut dengan bunga bank (atau bank tanpa bunga). Bank Syariah didasarkan pada sistem hasil bagi dan keuntungan maupun sistem sewa yang kesemunya itu didasarkan pada kesepakatan- kesepakatan. Sistem Bank Syariah dilandasi dengan Al-Quran dan Hadits. Mengingat bahwa setiap umat manusia dalam mengisi dan menjalani kehidupannya, perlu melakukan pengendalian dan mengetahui batasan berupa jalur hukum atau syariat islam yang harus dipedomaninya sesuai dengan $\mathrm{Al}-$ Quran dan sunah Rasul (Rivai 2013: 1). Hal ini sebagaimana Rasulullah saw bersabda :

"Telah aku tinggalkan atas kalian semua, suatu perkara jika kalian berpegang teguh di atasnya, maka kalian tidak akan tersesat selamanya setelah $k u$, yaitu kitab Allah (AlQuran) dan sunah-ku "(hadits). Disisi lain sistem syariah islam adalah sistem terbaik ciptaan Allah yang harus diikuti sesuai dalam Al-Quran surat Al-Jatsiyah (45:18) : "Kemudian kami jadikan kamu berada di atas suatu syariah (peraturan) dari urusan(agama itu), maka ikutilah syariah itu dan janganlah kamu ikuti hawa nafsu orang-orang yang tidak mengetahui".

Khususnya berkaitan dengan Bank Syariah (Istilah khusus di Indonesia) landasannya mengacu pada Al-Quran surat Ali-Imron ayat $130(3: 130)$ :

"Hai orang orang beriman, janganlah kamu memakan riba dengan berlipat ganda dan bertakwalah kamu kepada Allah supaya kamu mendapat keberuntungan".

Yang dimaksud riba di sini ialah riba nasi'ah. Menurut sebagian besar ulama bahwa riba nasi'ah itu selamanya haram, walaupun tidak berlipat ganda. Riba Fadhl 
ialah penukaran suatu barang dengan barang yang sejenis, tetapi lebih banyak jumlahnya karena orang yang menukarkan menyaratkan demikian, seperti penukaran emas dengan emas, padi dengan padi, dan sebagainya. Riba yang dimaksud dalam ayat ini Riba nasi'ah yang berlipat ganda yang umum terjadi dalam masyarakat Arab zaman Jahiliyah.

Dasar hukum dan kegiatan usaha Bank Syariah mendapatkan pijakan yang kokoh setelah deregulasi sektor perbankan pada tahun 1983 karena sejak saat itu diberikan keleluasaan penentuan tingkat suku bunga, termasuk yang nol persen (atau peniadaan bunga sekaligus). Sungguhpun demikian, kesempatan ini belum termanfaatkan karena tidak diperkenankannya pembukaan kantor bank baru. Hal ini berlangsung sampai tahun 1988 di mana pemerintah mengeluarkan Pakto 1988 yang memperkenankan berdirinya bank baru. Kemudian posisi perbankan Islam semakin pasti setelah disahkan UU Perbankan N0.7 Tahun 1992 dimana Bank diberikan kebebasan untuk menentukan jenis imbalan yang akan diambil dari nasabahnya baik bunga ataupun keuntungan keuntungan bagi hasil.

Bank Islam yang berada di Tanah Air tetap harus tunduk kepada peraturan peraturan dan persyaratan perbankan yang berlaku pada umumnya antara lain sebagai bewrikut :

1. Ketentuan perizinan dalam pengembangan usaha, sepereti pembukaan cabang dan kegiatan devisa

2. Kewajiban pelaporan ke Bank Indonesia

3. Pengawasan Intern
4. Pengawasan atas prestasi, permodalan, manajemen, rentabilitas dan factor yang lainnya.

5. Pengenaan sanksi atas pelanggaran

Adanya tuntutan perkembangan maka Undang Undang Perbankan No.7 Tahun 1992 kemudian direvisi menjadi Undang Undang Perbankan No,10 Tahun 1998. Undang Undang ini melakukan revisi beberapa pasal yang dianggap penting, dan merupakan aturan hukum secara leluasa menggunakan istilah syar'i dengan tidak lagi menggunakan istilah bagi hasil. Diantara perubahan yang berkaitan langsung dengan keberadaan bank Islam adalah sebagai berikut.

1. Pasal 1 ayat 12 menyatakan "Pembiayaan berdasarkan Prinsip Islam adalah penyediaan uang atau tagihan yang dipersamakan dengan itu berdasarkan persetujuan atau kesepakatan antara bank dengan pihak lain yang mewajibkan pihak yang dibiayai untuk mengembalikan uang atau tagihan tersebut setelah jangka waktu teretentu dengan imbalan atau bagi hasil"

2. Pasal 1 ayat 13 berbunyi" Prinsip Syariah Islam adalah aturan perjanjian berdasarkan hukum Islam antara bank dengan pihak lain untuk menyimpan dana dan pembiayaan kegiatan usaha, atau kegiatan lainnya yang dinyatakan sesuai dengan syariah Islam, antara lain pembiyaan berdasarkan prinsip bagi hasil (mudharabah), pembiyaan berdasarkan prinsip penyertaan modal (musyarakah), prinsip jual beli barang dengan memperoleh keuntungan (murabahah), atau pembiayaan barang modal berdasarkan prinsip sewa murni 
tanpa pilihan (ijarah), atau dengan adanya pilihan pemindahan kepemilikan atas barang yang disewa dari pihak bank oleh pihak lain (ijarah wa iqtina).

3. Ketentuan Pasal 6 huruf $m$ diubah, sehingga Paasal 6 huruf $m$ menjadi berbunyi sebagai berikut: "menyediakan pembiayaan dan atau melakukan kegiatan lain berdasarkan Prinsip Islam, sesuai dengan ketentuan yang ditetapkan oleh Bank Indonesia".

4. Ketentuan Pasal 13 huruf c diubah, sehingga Pasal 13 huruf $c$ menjadi berbunyi sebagai berikut : " menyediakan peniagaan dan penempatan dana berdasarkan Prinsip Islam, sesuai dengan ketentuan yang ditetapkan oleh Bank Indonesia ' ( UU No.10 Tahun 1998 ).

Asas, Tujuan dan Prinsip Bank Syariah

Pasal 3 Undang Undang Nomor 21 Tahun 2008, ditegaskan asas perbankan syariah, yang menentukan sebagai berikut :"Perbankan Syariah dalam melakukan kegiatan usahanya berasaskan Prinsip Syariah, demokrasi ekonomi, dan prisip kehati-hatian".

Dari ketentuan dalam Pasal 3 UndangUndang Nomor 21 Tahgun 2008 dapat diketahui secara jelas, bahwa perbankan syariah dalam melakukan kegiatan usahanya diwajibkan berasaskan dan mengimplementasikan prinsip syariah. Perbankan syariah adalah perbangkan yang berdasarkan kepada prinsip syariah.

Mengenai pengertian prinsip syariah diketemukan dalam ketentuan Pasal 1 angka 13 Undang Undang nomor 7 Tahun 1992 sebagaimana telah dirubah dengan Undang Undang No 10 Tahun 1998, yang megartikan Prinsip Syariah adalah aturan perjanjian beradasarkan hukum Islam antara bank dan pihak lain untuk penyimpanan dana atau pembiayaan kegiatan usaha, atau kegiatan lainnya yang dinyatakan sesuai dengan syariah, antara lain pembiayaan berdasarkan prinsip bagi hasil (mudharabah), pembiyaan berdasarkan prinsip penyertaan modal (musharakah), prinsip jual beli dengan memperoleh keuntungan (murababah), atau pembiayaan barang modal berdasarkan prinsip sewa murni tanpa pilihan (ijarah), atau dengan adanya pilihan pemindahan kepemilikan atas barang yang disewa dari pihak bank oleh pihak lain (ijarah wa iqtina) ".

Dalam Penjelasan Umum Atas Undang Undang No 21 Tahun 2008 antara lain dikemukakan Sementara itu, untuk memberikan keyakinan pada masyarakat yang masih meragukan kesyariahan operasional Perbankan Syariah selama ini, diatur pula kegiatan usaha yang tidak bertentangan dengan prinsip Syariah meliputi kegiatan usaha yang tidak mengandung unsure-unsur riba, maisir, gharar, haram, dan zalim.

Berdasarkan hal ini, maka mengandung arti, bahwa kegiatan usaha dan produk perbankan yang berasaskan prinsip syariah tersebut, antara lain adalah kegiatan usaha yang tidak mengandung unsur-unsur seperti yang tersebut dalam Penjelasan atas Pasal 2 Undang Undang Nomor 21 Tahun 2008, menurut Usman (2012: 116) yaitu :

1. riba, yaitu penambahan pendapatan secara tidak sah (batil) antara lain dalam transaksi pertukaran barang sejenis yang tidak sama kualitas, kuantitas, dan waktu penyerahan (fardhl), atau dalam transaksi 
pinjam-meminjam

mempersyaratkan

Penerima Fasilitas mengembalikan dana yang diterima melebihi pokok pinjaman karena berjalannya waktu (nasi'ah).

2. maisir, yaitu transaksi yang digantungkan kepada suatu keadaan yang tidak pasti dan bersifat untung untungan.

3. gharar, yaitu transaksi yang objeknya tidak jelas, tidak dimiliki, tidak diketahui keberadaannya, atau tidak dapat diserahkan pada saat transaksi dilakukan kecuali diatur lain dalam syariah,

4. haram, yaitu transaksi yang objeknya dilarang dalam syariah,atau

5. zalim, yaitu transaksi yang menimbulkan ketidakadilan bagi pihak lainnya

\section{Tinjauan Umum tentang Kepastian Hukum Pengertian Kepastian Hukum}

Kepastian hukum sangat penting dalam dunia ekonomi atau bisnis sebagai alat pengatur bisnis tersebut, kepastian hukum mutlak perlunya bagi pembangunan ekonomi. Tanpa adanya kepastian hukum pelaku-pelaku ekonomi khawatir akan keselamatan diri mereka. Antaralain karena tindakan perdata dapat dijadikan pidana karena aturan hukum tidak konsisten (Erman, 2012). Bahkan sebagai negara yang masih berkembang (developing country) Pemerintah Indonesia masih banyak persoalan yang masih harus diselesaikan. Karena masih banyak dipertanyakan oleh masyarakat Internasional dalam hal kepastian hukum (legal certainty), perlindungan hukum (legal protection) dan penegakan hukum (law enforcement) dalam berbagai bidang yang terjadi di tengah-tengah masyarakat (Syafrinaldi, 2010). Kemajuan suatu ekonomi/bisnis tidak akan berarti kalau kemajuan tidak berdampak pada kesejahteraan dan keadilan yang dinikmati secara merata oleh rakyat. Negara harus menjamin semua itu agar tidak ada terjadi pengusaha kuat menindas pengusaha lemah, yang kaya semakin kaya yang miskin semakin miskin, sehingga tidak ada keseimbangan dalam tatanan kehidupan masyarakat.

Kepastian hukum secara normatif adalah ketika suatu peraturan dibuat dan diundangkan secara pasti karena mengatur secara jelas dan logis. Jelas dalam artian tidak menimbulkan keragu-raguan (multitafsir) dan logis dalam artian menjadi suatu sistem norma dengan norma lain sehingga tidak berbenturan atau menimbulkan konflik norma. Konflik norma yang ditimbulkan dari ketidakpastian aturan dapat berbentuk kontestasi norma, reduksi norma atau distorsi norma (Hukum online, 2014). Menurut Sudikno Mertukusumo kepastian hukum merupakan sebuah jaminan bahwa hukum tersebut harus dijalankan dengan cara yang baik.

Meski obyektivisme adalah suatu yang tidak mungkin dalam hukum, ia diandaikan ada, yakni dalam dan berupa hukum positif namun kita dapat mengenali apa yang dilarang dan diperbolehkan dari hukum positif tersebut. karena itu, ius (keadilan) yang abstrak agar bisa diverifikasi harus dipositifkan (ius constitutum) terlebih dahulu menjadi rumusan hukum positif (Widodo, 2011). 


\section{Pandangan Para Ahli Mengenai Kepastian Hukum}

Keteraturan masyarakat berkaitan erat dengan kepastian dalam hukum, karena keteraturan merupakan inti dari kepastian itu sendiri. Keteraturan menyebabkan orang dapat hidup secara berkepastian sehingga dapat melakukan kegiatan-kegiatan yang diperlukan dalam kehidupan bermasyarakat. Guna memahami secara jelas mengenai kepastian hukum itu sendiri, berikut akan diuraikan pengertian mengenai kepastian hukum dari beberapa ahli.

Gustav Radbruch mengemukakan 4 (empat) hal mendasar yang berhubungan dengan makna kepastian hukum, yaitu : (Bernard, 2013)

1) Bahwa hukum itu positif, artinya bahwa hukum positif itu adalah perundang-undangan

2) Bahwa hukum itu didasarkan pada fakta artinya didasarkan pada kenyataan

3) Bahwa fakta harus dirumuskan dengan cara yang jelas sehingga menghindari kekeliruan dalam pemaknaan di samping mudah dilaksanakan

4) Bahwa hukum positif tidak boleh mudah diubah.

Pendapat Gustav Radbruch memahami hukum sebagai "ilmu kultur empiris dan normatif". Dengan kata lain Radbruch mengkombinasikan dua pendekatan sekaligus yaitu pendekatan normatif dan pendekatan empiris. Bagi Radbruch ilmu hukum adalah pengetahuan tentang hal-hal yang bersifat atau bersumber dari manusia maupun dari Tuhan. Ilmu tentang apa yang adil dan apa yang tidak adil, Radbruch juga mempunyai metode yang bersifat dualis, yang secara tajam memisahkan antara nilai dan fakta, the "ought" (Sollen) dan the "is" (Sein). (Ahmad, 2010).

Pendapat mengenai kepastian hukum dikemukakan pula oleh Jan M. Otto sebagaimana dikutip oleh Sidharta, yaitu bahwa kepastian hukum dalam situasi tertentu mensyaratkan sebagai berikut:

1. Tersedia aturan-aturan hukum yang jelas atau jernih, konsisten dan mudah diperoleh (accesible) yang diterbitkan oleh kekuasaan negara

2. Bahwa instansi-instansi penguasa (pemerintahan) menerapkan aturanaturan hukum tersebut secara konsisten dan juga tunduk dan taat kepadanya

3. Bahwa mayoritas warga pada prinsipnya menyetujui muatan isi dan karena itu menyesuaikan perilaku mereka terhadap aturan-aturan tersebut

4. Bahwa hakim-hakim (peradilan) yang mandiri dan tidak berpihak menerapkan aturan-aturan hukum tersebut secara konsisten sewaktu mereka menyelesaikan sengketa hukum

5. Bahwa keputusan peradilan secara konkrit dapat dilaksanakan.

Kelima syarat yang dikemukakan Jan M. Otto tersebut menunjukkan bahwa kepastian hukum dapat dicapai jika substansi hukumnya sesuai dengan kebutuhan masyarakat. Aturan hukum yang mampu menciptakan kepastian hukum adalah hukum yang lahir dari dan mencerminkan budaya masyarakat. Kepastian hukum yang seperti inilah yang disebut dengan kepastian hukum yang sebenarnya (realistic legal certainly). Yaitu mensyaratkan adanya keharmonisan antara negara dengan rakyat dalam berorientasi dan memahami sistem hukum. 
Menurut Sudikno Mertokusumo, kepastian hukum adalah jaminan bahwa hukum dijalankan. Bahwa yang berhak menurut hukum dapat memperoleh haknya dan bahwa putusan dapat dilaksanakan. Walaupun kepastian hukum erat kaitannya dengan keadilan namun hukum tidak identik dengan keadilan, hukum bersifat umum, mengikat setiap orang, bersifat menyamaratakan sedangkan keadilan bersifat subyektif, individualistis, dan tidak menyamaratakan (Sudikno, 1998).

Kepastian hukum merupakan pelaksanaan hukum sesuai dengan bunyinya sehingga masyarakat dapat memastikan bahwa hukum dilaksanakan. Dalam memahami nilai kepastian hukum yang harus diperhatikan adalah bahwa nilai itu mempunyai relasi yang erat dengan instrumen hukum yang positif dan peranan negara dalam mengaktualisasikannya pada hukum. Persyaratan internal tersebut adalah sebagai berikut: Pertama, kejelasan konsep yang digunakan. Norma hukum berisi deskripsi mengenai perilaku tertentu yang kemudian disatukan ke dalam konsep tertentu pula. Kedua, kejelasan hirarki kewenangan dari lembaga pembentuk peraturan perundang-undangan. Kejelasan hirarki ini penting karena menyangkut sah atau tidak dan mengikat atau tidaknya peraturan perundang-undangan yang dibuatnya. Kejelasan hirarki akan memberi arahan pembentuk hukum yang mempunyai kewenangan untuk membentuk suatu peraturan perundangundangan tertentu. Ketiga, adanya konsistensi norma hukum perundangundangan. Artinya ketentuan-ketentuan dari sejumlah peraturan perundangundangan yang terkait dengan satu subyek tertentu tidak saling bertentangan antara satu dengan yang lain.
Kepastian hukum menghendaki adanya upaya pengaturan hukum dalam perundang-undangan yang dibuat oleh pihak yang berwenang dan berwibawa. Sehingga aturan-aturan itu memiliki aspek yuridis yang dapat menjamin adanya kepastian bahwa hukum berfungsi sebagai suatu peraturan yang harus ditaati. Lon Fuller dalam bukunya The Morality of Law mengajukan 8 (delapan) asas yang harus dipenuhi oleh hukum apabila tidak terpenuhi maka hukum akan gagal untuk disebut sebagai hukum. Atau dengan kata lain harus terdapat kepastian hukum kedelapan asas tersebut adalah sebagai berikut: (lon, 1971).

1) Suatu sistem hukum yang terdiri dari peraturan-peraturan, tidak berdasarkan putusan-putusan sesat untuk hal-hal tertentu

2) Peraturan tersebut diumumkan kepada publik

3) Tidak berlaku surut karena akan merusak integritas sistem

4) Dibuat dalam rumusan yang dimengerti oleh umum

5) Tidak boleh ada peraturan yang saling bertentangan

6) Tidak boleh menuntut suatu tindakan yang melebihi apa yang bisa dilakukan

7) Tidak boleh sering diubah-ubah

8) Harus ada kesesuaian antara peraturan dan pelaksanaan sehari-hari.

Pendapat Lon Fuller di atas dapat dikatakan bahwa harus ada kepastian antara peraturan dan pelaksanaannya. Dengan demikian sudah memasuki ranah aksi, perilaku, dan faktor-faktor yang mempengaruhi bagaimana hukum positif dijalankan. Dari uraian-uraian mengenai kepastian hukum di atas maka kepastian dapat mengandung beberapa arti yakni adanya kejelasan tidak menimbulkan 
multitafsir tidak menimbulkan kontradiktif dan dapat dilaksanakan. Hukum harus berlaku tegas dalam masyarakat mengandung keterbukaan sehingga siapapun dapat memahami makna atas suatu ketentuan hukum. Hukum yang satu dengan yang lain tidak boleh kontradiktif sehingga tidak menjadi sumber keraguan. Kepastian hukum menjadi perangkat hukum suatu negara yang mengandung kejelasan, tidak menimbulkan multitafsir, tidak menimbulkan kontradiktif serta dapat dilaksanakan yang mampu menjamin hak dan kewajiban setiap warga negara sesuai dengan budaya masyarakat yang ada.

\section{METODE}

Dalam penelitian ini menggunakan pendekatan yuridis normatif (Soekanto, 1985), yaitu pendekatan yang mengkaji kaidah-kaidah hukum normatif atau doktrinal dan menggali azas-azas hukum terkait dengan pelaksanaan fungsi akad murabahah dalam memenuhi keinginan masyarakat untuk membeli rumah melalui Pembiayaan Pemilikan Rumah (PPR). Soerjono Soekanto pada penelitian hukum sosiologis atau empiris, maka yang dapat diteliti pada awalnya adalah data sekunder kemudian dilanjutkan dengan penelitian terhadap data primer dilapangan, atau terhadap masyarakat. Penelitian ini bersifat deskriptif analitis dengan maksud untuk memperoleh gambaran mengenai pelaksanaan akad murabahah dalam Pembiayaan Pemilikan Rumah (PPR) pada bank syariah dihubungkan dengan tujuan perbankan syariah tersebut. Sumber data dalam penelitian ini menggunakan data sekunder, yaitu data Sekunder (Library Research). (Pieter, 2010). Namun diperkaya juga dengan data primer dan tersier yang terdiri dari; Bahan Hukum primer, Bahan hukum dan Bahan hukum Tersier. Adapun analisis data yang digunakan oleh peneliti dalam penelitian ini menggunakan sifat analisis yang deskriptif adalah, bahwa memberikan gambaran atau pemaparan atas subjek dan objek penelitian, data yang diteliti dan dipelajari sebagai sesuatu yang utuh (Muchti, 2010). Setelah itu penulis mengambil kesimpulan dengan metode deduktif, yaitu cara penarikan kesimpulan dari hal-hal yang bersifat umum kepada ketentuan ketentuan yang bersifat khusus.

\section{HASIL}

\section{Kepastian Hukum Akad Murabahah dalam Jual Beli rumah Pandangan Ulama}

Terdapat beberapa pendapat ulama tentang operasionalisasi produk bai' almurabahah di dalam perbankan syari'ah, yaitu : Bai' al-murabahah merupakan bai' al-'inah yang diharamkan. Bai' al-'Inah adalah suatu akad jual-beli di mana seseorang (penjual) menjual suatu barang kepada orang lain (pembeli) secara kontan, kemudian penjual tersebut membeli kembali barang tersebut secara tempo dengan harga yang lebih tinggi. Menurut Wahbah az-Zuhaili, akad jual-beli ini hanya merupakan hilah menuju akad pinjammeminjam yang mengandung riba dengan jalan atau perantaraan akad jual-beli. Bai' al-murabahah merupakan jual beli barang yang tidak ada pada seseorang (bai' alma'dum). Larangan menjual barang yang tidak ada pada seseorang itu sendiri. Menurut al-Baghawi, yang dikutip oleh asySyaukani, bahwa larangan di dalam hadis tersebut adalah larangan menjual barang yang belum dimiliki. Adapun menjual sesuatu yang ada di dalam tanggungan itu 
boleh secara akad salam dengan syaratsyarat tertentu.

Jika seseorang menjual sesuatu yang ada dalam tanggungannya dan ditentukan secara konkret di tempat yang telah diperjanjikan, maka hal itu boleh, meskipun barang tersebut belum ada pada waktu akausuf, 1989). Menurut Ibn Taimiyah larangan tersebut bukan dari segi ada/ tidaknya objek akad, tetapi disebabkan oleh adanya unsur garar, yaitu jual-beli sesuatu yang tidak dapat diserahkan. Bai' almurabahah merupakan dua jual beli dalam satu jual beli (bai'atâni fî bai'ah). Larangan adanya dua jual-beli dalam satu jual-beli Menurut ulama Hanafiyah, akad jual-beli ini fâsid karena harganya tidak jelas dan disertai dengan syarat tertentu. Demikian pula menurut ulama Syafi'iyah dan Hambaliyah, akad jual-beli ini batal karena termasuk jual-beli yang mengandung gharar.

Sedangkan menurut Imam Malik, akad jual-beli ini sah karena dua jual-beli dalam satu jual-beli adalah dua harga yang berbeda antara kontan dan tempo, tinggal pembeli memilih antara keduanya. Bai' almurâbahah merupakan hîlah untuk mengambil riba dan bentuk lain dari financing (bank konvensional). Ada sebagian ulama yang berpandangan bahwa bai' al-murabâhah dalam praktik perbankan syari'ah merupakan hîlah untuk memperoleh riba atau menghasilkan uang sebagaimana yang dilakukan oleh bank konvensional. Pada hakikatnya pembeli (nasabah) datang ke bank untuk mendapatkan pinjaman uang, dan bank tidak membeli barang (aset) kecuali dengan maksud untuk menjual barang kepada pembeli (nasabah) secara kredit. Hal tersebut kemungkinan didasarkan kepada anggapan bahwa mekanisme penetapan harga (pricing) di dalam pembiayaan bai' al-murabâhah menggunakan cara perhitungan yang sama dengan bank konvensional, yaitu dalam bentuk prosentase dari pembiayaan pertahun $(\%$ p.a).

Perbedaannya, di dalam bank konvensional, yang menjadi hutang nasabah terdiri dari pinjaman pokok dan hutang bunga (biaya dalam prosentase pertahun) yang wajib dibayar oleh nasabah secara tetap selama pinjaman pokok belum dilunasi. Demikian pula masih dimungkinkan adanya kenaikan suku bunga tanpa harus ada persetujuan dari pihak nasabah sehingga jumlah margin keuntungan menjadi tidak jelas karena tergantung kepada lamanya pembayaran dan besarnya suku bunga yang ada.

\section{Menurut Hukum positif}

Pelaksanaan konsep jual beli secara murabahah pada Bank BRI Syariah Pekanbaru belum dilaksanakan karena pihak bank seharusnya membeli rumah terlebih dahulu kepada pihak develover baru menjualnya kepada pihak konsumen/calon nasabah. Namun hal tersebut tidak dilaksanakan, sistem jual beli tersebut tidaklah termasuk ke dalam bentuk jual beli Murabahah sebagaimana yang dimaksud oleh Fatwa DSN No. 04/DSN-MUI/IV/2000 tentang Ketentuan Umum Murabahah dalam Bank Syariah Jo. PBI No. 7/46/PBI/2005 tentang Akad Penghimpunan Dan Penyaluran Dana Bagi Bank Yang Melaksanakan Kegiatan Usaha Berdasarkan Prinsip Syariah.

Dengan sistem tersebut pada kenyataannya jual beli yang terjadi adalah jual beli antara Pengembang dengan nasabah dan peranan bank disini hanya sebagai penyedia pembiayaan saja bukan sebagai penjual. Disamping itu 
pelaksanaan jual beli murabahah pada Bank BRI Syariah Pekanbaru belum dilakukan sesuai dengan ketentuan yang berlaku karena masih terdapat praktik peralihan hak atas tanah secara di bawah tangan. Hal ini tidak sesuai dengan PP No. 24 Tahun 1997 tentang Pendaftaran Tanah Jo. Peraturan Menteri Agraria/KBPN No. 3 Tahun 1997. Penyimpangan ini terjadi karena bank pada kenyataannya dihadapkan pada kendala-kendala dalam penyaluran pembiayaan murabahah terutama sekali kendala dari segi peraturan perundang-undangan yang memang pada kenyataannya sulit untuk dilaksanakan karena dipandang dapat merugikan dan sangat melemahkan pihak bank. Secara umum, akad yang sering digunakan dalam pembiayaan rumah ini antara lain adalah murabahah (jual beli dengan marjin profit) terutama untuk rumah yang telah dibangun. PPR murabahah adalah perjanjian jual beli antara bank dan nasabah, dimana bank membeli rumah yang diperlukan nasabah dan kemudian menjualnya kepada nasabah sebesar harga beli ditambah dengan margin keuntungan yang disepakati oleh bank dan nasabah. Ada juga yang menambahkan akad wakalah dalam PPR syariah.

\section{Kreativitas hukum untuk mencapai tujuan perbankan syariah}

Kreativitas hukum yang dimaksud dalam penelitian ini adalah; secara konsep jual beli yang terjadi tidak dapat dilaksanakan namun karena kebutuhan masyarakat luas begitu mendesak maka dicari dasar agar jual beli tersebut dapat dilaksanakan. indikatornya adalah;

1) Titik berat aliran sociological jurisprudence terletak pada kenyataan sosial yang dapat menjadi kenyataan hukum (fakta hukum).
Fakta-fakta hukum yang mendasari semua hukum adalah kebiasaan, dominasi, pemilikan dan pernyataan kemauan. Menurut Roscoe Pound melalui karya besarnya yang berjudul "Scope and Purpose of Sociological Jurisprudence" pada tahun 1912. Inti pemikiran dari aliran ini terletak pada penekanan bahwa hukum yang baik yang sesuai dengan hukum yang hidup dimasyarakat (Erwin, 2013).

2) Fungsi hukum sebagai sarana pengendalian sosial dan rekayasa sosial. Undang-undang tidak dapat dibuat semata-mata atas pertimbangan rasional dan keinginan para pembuatnya melainkan dilakukan melalui kajian sosiologis pada waktu dilakukan persiapan untuk membuatnya (Satjipto, 2010).

3) Mempelajari efek sosial yang nyata dari lembaga-lembaga serta ajaranajaran hukum

4) Melakukan studi sosiologis dalam rangka mempersiapkan perundangundangan untuk mempelajari pelaksanaannya dalam masyarakat serta efek yang ditimbulkan untuk kemudian dijalankan. Karena peraturan yang dibuat harus sesuai dengan apa yang menjadi kebutuhan masyarakat saat sekarang ini.

5) Struktur suatu masyarakat selalu berada dalam kondisi yang kurang imbang. Ada yang terlalu dominan dan adapula yang terpinggirkan. Untuk menciptakan dunia yang beradab ketimpangan-ketimpangan struktural itu perlu ditata ulang dalam urutan pola keseimbangan yang proposional. Dalam konteks 
keperluan yang demikian itu, hukum yang bersifat logis-analitis dan serba abstrak (hukum murni) ataupun yang berisi gambaran realitas apa adanya (sosiologis) tidak mungkin diandalkan. Dari sinilah muncul teori Pound tentang "law as a tool of social engineering".

6) Kepentingan umum (public interest). Kepentingan umum adalah kepentingan yang dalam menjaga kepentingan rakyat dimana negara memiliki kewajiban untuk menjaga apa yang menjadi kepentingan dari masyarakat pada saat ini dalam hal perbankan syariah yang semakin berkembang di Indonesia pada saat sekarang ini.

7) Kepentingan negara sebagai badan hukum. Adalah negara sebagai badan hukum berfungsi dan berperan memberikan perlindungan dan kepastian hukum terhadap masyarakat dalam hal ini mengenai kebijakan-kebijakan pemerintah dalam membuat peraturan perundang-undangan yang dapat bermanfaat bagi masyarakat. Dengan memberikan kebijakan apa yang diperlukan oleh pihak penjual yakni pihak bank syariah dan pembeli adalah konsumen. Negara bertujuan memberikan kesejahtaraan dan tempat tinggal yang layak buat warga negaranya untuk mewujudkan hal tersebut negara dapat membuat sebuah kebijakan dalam hal memberikan keringan pajak bagi pihak bank dalam melakukan pembelian kepada pihak developer atau menghapuskan pajak pembelian yang dilakukan oleh pihak bank kepada supplier yang mana hal tersebut bertujuan untuk memberikan kemudahan bagi masyarakat dan merupakan salah satu kepentingan negara.

8) Kepentingan masyarakat (social interest). Kepentingan pribadi adalah kepentingan yang sesuai dengan apa yang dibutuhkan dengan masyarakat saat ini. Melihat perkembangan perekonomian serta pertumbuhan masyarakat maka rumah sebagai sarana tempat tinggal merupakan salah satu hal yang sangat penting bagi masyarakat untuk menjadi tempat tinggalnya. Selain kepentingan masyarakat terhadap rumah yang sangat dibutuhkan juga adalah sebuah lembaga yang dapat melakukan pembiayaan terhadap pembayaran rumah yang dalam hal ini adalah pihak bank. Indonesia merupakan salah satu negara yang sangat banyak umat muslimnya. Oleh karena itu konsep pembiayaan melalui perbankan syariah di Indonesia merupakan salah satu hal yang sangat dibutuhkan oleh masyarakat, apalagi saat ini perkembangan perbankan syariah di Indonesia sudah sangat pesat seiring dengan semakin meningkatnya kepentingan masyarakat terhadap perbankan syariah di Indonesia.

9) Kepentingan pribadi (private interest). Yaitu berupa pendekatan terhadap hukum sebagai jalan ke arah tujuan sosial dan sebagai alat dalam perkembangan sosial. Jika kita lihat banyaknya perbankan syariah di Indonesia saat sekarang ini yang bertujuan untuk memenuhi kebutuhan masyarakat Indonesia 
salah satunya mengenai kepemilikan rumah melalui PPR. Oleh sebab itu pihak bank selaku pemilik dana terus berusaha memberikan pelayanan yang terbaik kepada masyarakat dalam hal kepemilikan rumah dengan konsep murabahah. Salah satu cara yang dilakukan oleh pihak bank dengan cara memberikan kesempatan kepada konsumen untuk dapat melakukan pembayaran terhadap rumah yang diinginkan dengan cara mencicil dalam jangka waktu 5-15 tahun dengan suku bunga yang rendah dan flat (tetap). Hal ini merupakan salah satu tujuan pihak perbankan syariah dalam memenuhi kepentingan pribadi masyarakat dalam hal kepemilikan rumah dengan cara PPR Murabahah pada perbankan syariah di Indonesia.

\section{SIMPULAN}

Berdasarkan hasil penelitian serta analisis dan pembahasan yang telah penulis lakukan pada bab-bab terdahulu, berikut disajikan kesimpulan yang merupakan jawaban terhadap permasalahan dalam penelitian ini sebagai berikut:

1. Penerapan Akad Murabah untuk membeli rumah dengan Pembiayaan Pemilikan Rumah (PPR) pada BRI Syariah Pekanbaru tidak dapat dijalan secara murni sesuai dengan Keputusan DSN. No. 04/ DSN-MUI/ 2000 tentang Murabahah, hal ini disebabkan beberapa hal antara lain; (i). Bank sebagai badan hukum adalah lembaga penerima simpanan dan penyaluran dana dari dan kepada masyarakat bukan sebagai agen. (ii). Kemampuan bank untuk membeli terlebih dahulu barang yang dikehendaki masyarakat terbatas dari segi dana, tenaga pengelola, tempat penampungan dan perawatan barang yang dibeli sangat terbatas. (iii). Peraturan perundang undangan yang mengatur lembaga keuangan syariah belum terpisah dari peraturan yang mengatur bank konvesional.

2. Kepastian hukum pelaksanaan Akad Murabahah yang menggunakan wakalah tersebut merupakan kreasi hukum;

Akad murabahah merupakan

kepastian hukum alamiah/ natural certainty contract, yaitu suatu jenis kontrak transaksi dalam bisnis yang memiliki kepastian keuntungan dan pendapatan baik dari segi jumlah maupun dari segi penyerahannya, masing-masing pihak yang terlibat dapat melakukan prediksi terhadap pembayaran maupun waktu pembayarannya. Dengan demikian, sifat transaksinya fixed (tetap), dan predetermined (dapat ditentukan besarnya) dari sisi ini akad Murabahah lebih baik dari Perjanjian Kredit Bank Konvensional.

\section{DAFTAR RUJUKAN}

Achmad Ali, Menguak Teori Hukum (Legal Theory) dan Teori Peradilan (JudicialPrudence) termasuk Interpretasi Undang-undang (Legisprudence), Kencana, Jakarta, 2010

Adiwarman A. Karim, Islamic Microeconomics, first edition, Muamalat Istitute, Jakarta, 2001 
Anton F. Susanto, Dekonstuksi Hukum Eksploitasi Teks Dan Model Pembacaan, Genta Publishing, Yogyakarta, 2010

Johannes Ibrahim, Mengupas Tuntas Kredit Komersial dan Konsumtif dalam Perjanjian Kredit Bank, CV Mandar Maju, Bandung, 2004

Bernad L Tanya, Yoan N Simanjuntak dan Markus Y Hage, Teori Hukum Strategi Tertib Manusia Lintas Ruang dan Generasi, Genta Publishing, Yogyakarta, 2013

M. Faruq An-Nababan, Sistem Ekonomi Islam Pilihan Setelah Kegagalan sistem Kapitalis dan Sosialis, UII Pres, Cet ke-3, Yogyakarta, 2002

Peter Mahmud Marzuki, Pengantar IImu Hukum, Kencana Pranada Media Group, Jakarta, 2008

Satjipto Rahardjo, Pemanfaatan Ilmu-ilmu Sosial Bagi Pengembangan Ilmu Hukum, Genta Publishing, Yogyakarta, 2010

Satjipto Rahardjo, Sosiologi Hukum Perkembangan Metode dan Pilihan Masalah, Genta Publishing, Yogyakarta, 2010

Soerjono Soekanto, Persfektif Teoritis Studi Hukum Dalam Masyarakat, Rajawali Press, Jakarta, 1985

Sudikno Mertoskusumo, Mengenal Hukum (Suatu Pengantar), Liberty, Yogyakarta, 1988

Syafrinaldi, Hukum Tentang Perlindungan Hak Milik Intelektual Dalam Menghadapi Era Globalisasi, Uir Pres, Pekanbaru, 2010

Widodo Dwi Putro, Kritik Terhadap Paradigma Positivisme Hukum, Genta Publishing, Yogyakarta, 2011

Syukri Iska, Sistem Perbankan Syariah di Indoensia (Dalam Persfektif Fiqih
Ekonomi), Fajar Media Press, Yogyakarta, 2012

Sunarto Zulkifli, Panduan Praktis Transaksi Perbankan Syariah, Zikrul, Hakim, Jakarta, 2007

Bagya Agung Prabowo, Konsep Akad Murabahah Pada Perbankan Syariah (Analisa Krtis Terhada Aplikasi Konsep Akad Murabahah Di Indonesia Dan Malaysia, Volume XVI No. 1 Tahun 2009 Edisi Januari

Erman Rajagukguk, makalah Disampaikan pada diskusi "Peran dan Komitmen BUMN/BUMD dalam Memerangi PraktikBisnis yang Koruptif dalam Kaitan Pemberantasan Tindak Pidana Korupsi", diselenggarakan KomisiPemberantasan Korupsi (KPK), Jakarta 4 Juni 2012

Mukhti Fajar dan Yulianto Achmad. Dualisme Hukum Normatif dan Empiris.Yogyakarta.Pustaka Pelajar, 2010.

al-atsariyyah.com/jual-beli-dengan-cara-al'inah.html diakses pada tanggal 26 Februari 2015

Kitab Undang-Undang Hukum Perdata.

Fatwa Dewan Syariah Nasional Nomor 04/DSN-MUI/IV/2000

SYARIKAT : Jurnal Rumpun Ekonomi Syariah Volume 2, Nomor 1, Juni 2019 